\title{
Mitigation Of Black-Spot's on Highways by The Application of Safe System Approach
}

\author{
Dinesh K Yadav*1, Sujesh D. Ghodmare², N. Naveen Kumar ${ }^{3}$ \\ 1,2Department of Civil Engineering, G. H. Raisoni College of Engineering, Nagpur, Maharashtra, India \\ ${ }^{3}$ Road Safety Auditor, Hivista Projects Pvt Ltd, Nagpur, Maharashtra, India
}

Article Info

Volume 8, Issue 4

Page Number : 583-591

\section{Publication Issue}

July-August-2021

\section{Article History}

Accepted : 10 Aug 2021

Published : 16 Aug 2021

\section{ABSTRACT}

With increase in traffic volume across the globe traffic safety has come into highlight and become a major concern. Apparently, with due increase in traffic volume resulting in higher road accidents which considerably causes negative impact on economic growth, public health and general welfare of wellbeing. In the present scenario challenges are faced to mitigate the traffic volume and by making road users aware with road safety parameters which may results in less road fatalities. The root cause of an accidents intends to perception, intellection emotion and violation. The approach towards this research is to get minimal setback/casualties of the road. In order to gain the best possible course of action, the stretch of $8 \mathrm{KM}$ of National highway (NH-66) situated in a plain terrain in the district of Alapphuza, Kerala India. To begin with, accident data has been collected from NHAI office and Police station of above location with proper analysis by Accident Severity Index (ASI) method has been carried out. Adding to an idea, location of Black Spot has been identified by ASI method. Based on Severity of accident short term and long-term measures has been adopted. Eventually, after analyzing short term measures 10 black spot location along with the estimate has been worked out.

Keywords : Accident Severity Index, Black-Spots, NHAI, Road Safety Parameters.

\section{INTRODUCTION}

India has second highest population in the world so it requires a substantial transportation services like air, land and water transportation. Road transportation is the only means of transportation which has keen insight in all areas and responsible for door-to-door service. Hence it is extremely important to enhance and sustain the road network of our country. But on the other hand, with increase in population the number of vehicles is also increasing which are responsible for occurrence of a greater number of accidents. This causes an obstruction for the economic and social growth of the country. 
According to World Health Organization (WHO) road accidents are the leading cause of death amongst people aged in between 15-29. Applications of safety measures are not economical, but overall result has profitable, but limited funds put restrictions on the number of sites that may be treated. Therefore, it is necessary to pinpoint the high-risk stretches on the Highway and provide safety measures on those stretches on a priority in order to utilize the limited fund as effectively as possible.

According to MORT\&H "Black spot is a stretch on a Highway of about $500 \mathrm{~m}$ in Length in which either 5 road accidents (in all three years put together involving [fatalities grievous injuries) took place during the Last 3 years or 10 fatalities (in all three years put together) took place during the Last 3 years."

\section{OBJECTIVES}

The main objective of this research is:

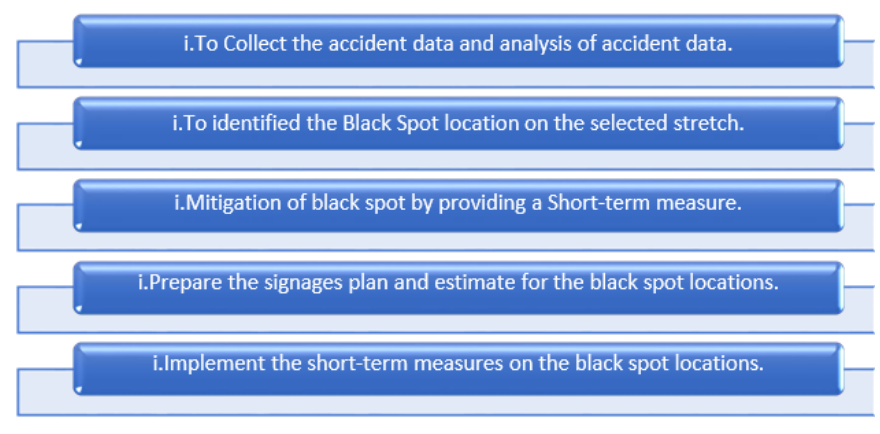

III. LITERATURE REVIEW

Relevant work has been conducted on engineeringbased counter measure development for improvement of safety performance.

Riadh et al [1] With the use of Spatial Data Analysis Method (Moran's I and Getis-Ord) Riadh et al. has recognized the computative cluster location of the road accidents "Black Spots" and the outcome validates that the Black Spots figures are higher than affirmed by public authorities i.e.,
20 Black Spots at odds with 9 Black Spots. Moreover, this method defines the actual classification of the scope. Hence, the Black Spots are codifying by their danger degree. Studies shows that Black Spot span detected by the method is less important versus the Public Authority of Road Safety (2000m vs $7000 \mathrm{~m}$ ). This implicit that it is feasible to minimize the Insecurity Cost by $71 \%$. Furthermore, this suggested classification gives safe infrastructure in the matter of Public Expenditure need.

Chen et al. [2] by means of Geo-spatial information has recorded the traffic casualties which shows how to make use of Geo-coding technology and VRS-GPS positioning technology. Two-way association relationship is defined by Spatial relationship computation which is based on the Spatial relationship between the traffic accidents and road network elements. This paper illustrated the technique which tends to minimize accidents which leads to uproot the Black spots. Ultimately, in the analysis, the association between Black spots and Traffic attributes is used to examine the factors that caused traffic accidents.

Medury et al [3] has suggested a Dynamic programming-based Hot Spot identification approach which allows the efficient Hot Spot definitions for Pedestrian Crashes. To correlate with the proposed approach, sliding window method and Intersection buffer-based approach is taken into consideration. The outcomes shows that the Dynamic Programming method produce more Hot Spots with a higher number of Crashes, while providing small Hot Spot Segment length. Whereas, due to first-come-first serve approach the sliding window method is shown to suffer from shortcomings and vice versa, Hot Spot identification and a fixed Hot Spot window length assumption.

Ghodmare et al (2019) [4] has gone through the comparative analysis by taking BRTS and MRTS, 
which are costly in terms of investment and in terms of environmental impacts, MRTS is more productive than BRTS. If Intelligent Transportation System is incorporated the service of both systems may come up with more efficiency. It can be asserted that combination of various public transportation system should be well organized through the stages of design taking into account the integrated approach as a need for convenient public transportation system.

Honnappanavar et al. (2015) [5] canvass the present state of Traffic Accidents Information on SH-

85 from Tavarekee to Magadi Town in Karnataka State. They have also limelight the identification of Black Spots by using Weighted Severity Index method. For analyzing and prioritizing the black spots GIS software is used. To mitigate the Black Spots and to provide an improved traffic safety, engineering measures are also adopted.

Ghodmare et al (2019) [6] With the use of Multi Attribute Utility technique has estimated the sustainability index which is based on combination of individual performance measures for emerging metropolitan city of Nagpur. The outcome achieved is used in sustainability evaluation process for any corridor easily. For comparing the results of sustainability evaluation in different scenarios, this technique is adopted.

Nikhil et al. (2013) [7] used the idea in which the accidents were classified based on the severity of injuries. From year 2002-2011, accident data with total number of accidents for each year for Banglore city was acquired from the Banglore City Police was obtained. This accident data was compared with the Karnataka State data and accident data from Gorguntepalya and Jalahalli was studied. The classified volume count data i.e., the number of vehicles per day passing at different locations was found out plus the corrective measures for selected spots were proposed.
Mandloi et al. (2003) [8] suggested a procedure to identify the Black Spots location on roads. With the use of Geographic Information System (GIS) ARCVIEW 3.1 this procedure comprises of a model which implements prioritization of roads for accident casualties. The factors required for the analysis are grouped using Microsoft Visual Basic6.0 and Microsoft Visual C++6.0 software packages. This model is examined on the road network in BITS PILANI, henceforth, the outcomes are examined/analyzed to get the most accurate data for the model.

Apparao et al. [9] talked through the present state of traffic accident information on NH-58 from Meerut to Muzaffarnagr in Uttarakhad State. It also focuses on identification of High-Rate accident location by GIS Software and safety deficient areas on the highway. Thus, considerable course of action should be taken on Black Spots and traffic safety provisions should be adopted.

Metre et al (2021) [10] has investigated the Nagpur city in India in the context of compact city. The development concept is theoretical elements of the compact city. It attempts to examine the physiological aspects. The compactness of cities mostly relates to urban sustainability achieved by dense, mixed neighborhoods which makes the city more livable. Presently the developing cities have a negative impact as they cover large areas and conducive transport facilities tends to spread urban sprawl over large urban area. To restrict the impact of urban sprawl on the environment compact city concept is one of the most sustainable development approaches which is taken into account. As compared to India, there is a major difference between the city characteristics around the world. This paper reviews the compact city concept and attempt to explore its effects on sustainable development in the Indian condition. 
Wu et al. [11 Presented a research outlook achieved from the Highway Safety Enhancement Project (HSEP) that tends to safety performance on two-lane highways in Beijing, China. Potential factors are identified based on proposed evaluation criteria, and primary counter measures are developed against inferior driving conditions such as sharp curves, heavy gradients, continuous downgrades, poor sight distance, and poor clear zones. Six cost-effective engineering solutions were specifically executed to improve two lane highway safety conditions, including (1) traffic sign replacement, (2) repainting pavement markings, (3) roadside barrier installation, (4) intersection channelization, (5) drainage optimization, and (6) sight distance improvement. The effectiveness of these solutions was inspected and evaluated based on Empirical Bayes (EB) models. The results depicts that the proposed engineering solutions effectively improved traffic safety performance by significantly reducing crash occurrence risks and crash severities.

\section{RESEARCH METHODOLOGY}

1. The selected Project Study Area Stretch falling in the district of Alapphuza, Kerala and The

1. Project Road is National Highway (NH-66) situated in plain terrain. The total Project Length is $86.34 \mathrm{Km}$. Start point Ch.374+390 to end point at Ch. $460+730$.

2. The research stretch for the study is taken from google earth.

3. Chainage wise accident data will be collected from PWD, NHAI or road department along with the Nature of accident, Causes of accident, classification of accidents, Road features, whether condition.

4. Selected Stretch on a Highway or Expressway where accident prone area is to be found.

5. Selected parameters were inspected at every $100 \mathrm{~m}$ chainage. The stretch is highly prone to accidents. Parameters causing accidents are present at short intervals and therefore to achieve high degree of accuracy, chainage as small as $100 \mathrm{~m}$ was selected.

6. Comparison of real time data with records available in the police station and NHAI.

7. Separate out the accident data according to maximum accident occurring at particular spot.

8. To identify various traffic and road related factors causing accidents.

9. Separate out Accident data of past 3 years (from 2017 to 2019) bifurcated according to Nature of accident, Causes of accident, Type of Injury (Fatal, Grievous, and Minor), Road Feature, and Road Condition \& Weather Condition.

10. The reading taken on (selected site) then analyzed by accident severity index, according to importance of the parameter (ASI)

11. Give top rank and maximum weightage to the location on the basis of number of accidents occurred.

12. Analysis of the top ranked accidental spots.

13. The percentages after giving rank and weightage were calculated and on the basis of Accident

14. Severity Index (ASI) the accidental black spots were identified.

15. To carry out analysis of black spots by using statistical models.

16. Detailed analysis of the identified black spots and study the problems diagnosis at each black spots.

17. Counter measures for accidental spots will also be predicted.

18. Give the Improvement initiatives related to Geometric Design.

19. Comparison Proper measures for Rectification and implementations.

20. Black Spots will be rectified with support of accident data on these locations and will be reduced drastically after Implementation of short-term measures. 


\section{DATA COLLECTION AND ANALYSIS}

To determine the accident-prone area in our selected stretch on a highway the following data should be collected and analyze.

a. Chainage wise accident data will be collected from PWD, NHAI or road department along with the Nature of accident, Causes of accident, classification of accidents, Road features, whether condition.

b. Rough accident-prone locations as suggested by the

Police station.

\section{Bifurcation of Accident Data}

The accident data are studied of past 3 years (from 2017 to 2019) \& current year at their NHAI

office \& Police station and bifurcated according to Nature of accident, Causes of accident, Type of Injury (Fatal, Grievous, and Minor), Road Feature, and Road Condition \& Weather Condition.

Table 1. Classification of Accident according to their injury type

\begin{tabular}{|c|c|c|c|c|}
\hline Year & \multicolumn{3}{|c|}{ Injury Type } & \multirow{2}{*}{$\begin{array}{c}\text { Total } \\
\text { Accident }\end{array}$} \\
\cline { 2 - 4 } & Died & Grievous & $\begin{array}{c}\text { Minor } \\
\text { Iminen }\end{array}$ & \\
\hline 2017 & 59 & 235 & 97 & 391 \\
\hline 2018 & 56 & 278 & 104 & 438 \\
\hline 2019 & 48 & 271 & 141 & 460 \\
\hline 2020 & 15 & 140 & 55 & 210 \\
\hline
\end{tabular}

Classification of Accident according to their injury type

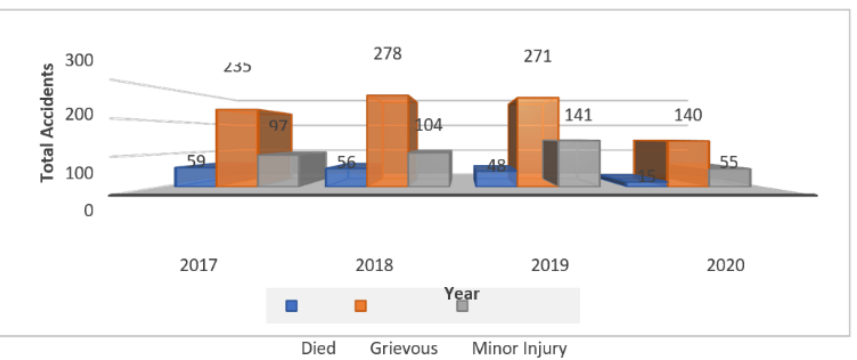

Figure 1. Classification of Accident according to their injury type

The figure shows that maximum members died in 2017, Grievous accidents are more in 2018, Major injury in 2019. The total accidents are more in 2019.

Table 2. Classification of Accident according to the Road Condition

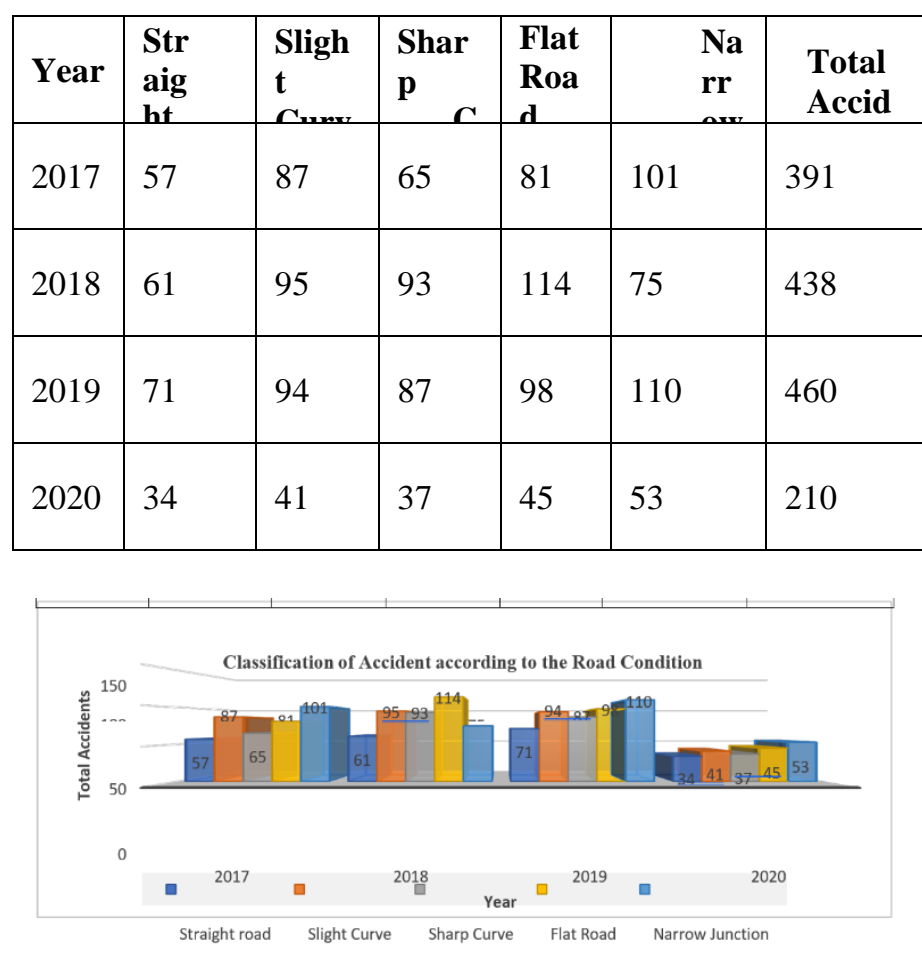

Figure 2. Classification of Accident according to the Road Condition.

The figure shows that maximum Straight Road accidents took place in 2019, accidents at slight curve is in 2018, at sharp curve is in 93 , at flat road is in 2018, at narrow junctions is in 2019. The total maximum accidents took place in 2019. 
Table 3. Classification of Accident according to the Nature of Accident

\begin{tabular}{|l|l|l|l|l|l|l|}
\hline Year & $\begin{array}{l}\text { Hi } \\
\text { fro } \\
\text { m } \\
\text { Side }\end{array}$ & $\begin{array}{l}\text { Hit } \\
\text { Pedest } \\
\text { rian }\end{array}$ & $\begin{array}{l}\text { Hit } \\
\text { from } \\
\text { Back }\end{array}$ & $\begin{array}{l}\text { Skiddin } \\
\text { g }\end{array}$ & $\begin{array}{l}\text { Head } \\
\text { on } \\
\text { collisi } \\
\text { on }\end{array}$ & $\begin{array}{l}\text { Tota } \\
\text { Icci } \\
\text { dent }\end{array}$ \\
\hline 2017 & 56 & 71 & 76 & 86 & 102 & 391 \\
\hline 2018 & 82 & 89 & 66 & 90 & 111 & 438 \\
\hline 2019 & 113 & 82 & 79 & 76 & 110 & 460 \\
\hline 2020 & 43 & 56 & 33 & 38 & 40 & 210 \\
\hline
\end{tabular}

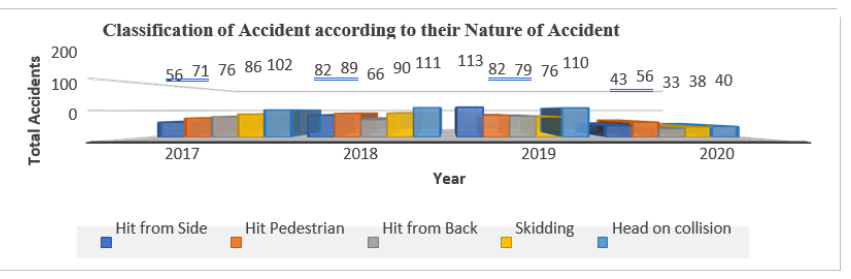

Figure 3. Classification of Accident according to the Nature of Accident.

The Figure shows that hit from side accidents took place more in 2019, Pedestrian hit in 2018, Hit from ack in 2019, Skidding accidents in 2018, Head on collision in 2018. The total accidents took place in 2019.
Analysis of Accident Data by Accident Severity Index Based on the Black Spot accident data collected, Accident Severity Index (ASI) is computed to identify the hazardous locations on the project corridor. In order to find the cruciality of an accident site, a system of assigning scores has been adopted based on the severity of accident. The score called as Accident Severity Index (ASI). Accident Severity Index is a dimensionless value indicating the level of hazard of a spot on the road. $\mathrm{T}$

he following equation has been used:

$\mathrm{ASI}=[\mathrm{Nf} \times \mathrm{Wf}]+[\mathrm{Ng} \times \mathrm{Wg}]+[\mathrm{Nm} \times \mathrm{Wm}]$ Whereas, $\mathrm{Nf}=$ No. of fatal accidents at the Patch in the past 3 years

$\mathrm{Wf}=6$ (Weightage assigned to fatal accident)

$\mathrm{Ng}=$ No. of grievous injury accidents at the spot in the past 3 years

$\mathrm{Wg}=3$ (Weightage assigned to grievous accident) $\mathrm{Nm}=$ No. of minor injury accidents at the Patch in the past 3 years

$\mathrm{Wm}=1$ (Weightage assigned to minor accidents.

Threshold Value $\mathrm{T}=\mathrm{v}+\left[1.5 \mathrm{x} \sqrt{ }\left\{\left(\sum(\mathrm{V}-\mathrm{v}) 2\right) /(\mathrm{N}-1)\right\}\right]$

$\mathrm{N}=$ No. of Black Spots

$\mathrm{V}=\mathrm{ASI}=$ Accident Severity Index

$\mathrm{V}=$ Average ASI

Standard Deviation $=\sqrt{ }\left\{\left(\sum(\mathrm{V}-\mathrm{v}) 2\right) /(\mathrm{N}-1)\right\}$

\section{RESULTS}

Table 4. ASI Values of the locations.

\begin{tabular}{|c|c|c|c|c|c|c|c|c|c|c|c|}
\hline S.NO & $\begin{array}{c}\text { Black } \\
\text { Spot } \\
\text { Location }\end{array}$ & $\begin{array}{c}\text { No. of } \\
\text { Fatal } \\
\text { Accident } \\
2017 \text { to } \\
2020\end{array}$ & $\begin{array}{l}\text { Weightage } \\
\text { for Fatal } \\
\text { accident }\end{array}$ & $\begin{array}{c}\text { No. of } \\
\text { Grevious } \\
\text { Accident } \\
2017 \text { to } \\
2020\end{array}$ & $\begin{array}{l}\text { Weightage } \\
\text { for Gevious } \\
\text { accident }\end{array}$ & $\begin{array}{c}\text { No. of } \\
\text { Minor } \\
\text { Accident } \\
2017 \text { to } \\
2020\end{array}$ & $\begin{array}{l}\text { Weightage } \\
\text { for Minor } \\
\text { accident }\end{array}$ & $\begin{array}{c}\text { ASI } \\
\text { Value }\end{array}$ & $\begin{array}{c}\text { Average } \\
\text { ASI }\end{array}$ & & \\
\hline & & $\begin{array}{l}\mathbf{N} \\
\mathrm{f}\end{array}$ & $\begin{array}{l}\text { W } \\
\mathbf{f}\end{array}$ & $\mathrm{Ng}$ & $\begin{array}{l}\text { W } \\
\mathbf{g}\end{array}$ & $\mathrm{Nm}$ & Wm & $\begin{array}{l}\text { ASI } \\
(\mathbf{V})\end{array}$ & $\mathbf{v}$ & $(\mathrm{V}-\mathrm{v})$ & $(\mathrm{V}-\mathrm{v})^{2}$ \\
\hline 1 & KL-176 & 1 & 6 & 4 & 3 & 1 & 1 & 221 & 132.4 & 88.6 & 7848.9 \\
\hline 2 & KL-177 & 1 & 6 & 4 & 3 & 2 & 1 & 226 & 132.4 & 93.6 & 8759.8 \\
\hline 3 & KL-178 & 3 & 6 & 2 & 3 & 7 & 1 & 100 & 132.4 & -32.4 & 1050.2 \\
\hline 4 & KL-179 & 2 & 6 & 1 & 3 & 2 & 1 & 56 & 132.4 & -76.4 & 5837.9 \\
\hline
\end{tabular}


Dinesh K Yadav et al Int J Sci Res Sci \& Technol. July-August-2021, 8 (4) : 583-591

\begin{tabular}{|c|c|c|c|c|c|c|c|c|c|c|c|}
\hline 5 & KL-180 & 1 & 6 & 5 & 3 & 2 & 1 & 254 & 132.4 & 121.6 & 14785.0 \\
\hline 6 & KL-181 & 1 & 6 & 5 & 3 & 5 & 1 & 26 & 132.4 & $\begin{array}{l}- \\
106.4\end{array}$ & 11322.3 \\
\hline 7 & KL-182 & 1 & 6 & 5 & 3 & 2 & 1 & 269 & 132.4 & 136.6 & 18657.9 \\
\hline 8 & KL-183 & 2 & 6 & 2 & 3 & 4 & 1 & 91 & 132.4 & -41.4 & 1714.5 \\
\hline 9 & KL-184 & 7 & 6 & 5 & 3 & 3 & 1 & 237 & 132.4 & 104.6 & 10939.9 \\
\hline 10 & KL-185 & 3 & 6 & 2 & 3 & 8 & 1 & 98 & 132.4 & -34.4 & 1183.8 \\
\hline 11 & KL-186 & 8 & 6 & 3 & 3 & 2 & 1 & 163 & 132.4 & 30.6 & 936.0 \\
\hline 12 & KL-187 & 1 & 6 & 4 & 3 & 1 & 1 & 209 & 132.4 & 76.6 & 5866.6 \\
\hline 13 & KL-188 & 2 & 6 & 7 & 3 & 5 & 1 & 38 & 132.4 & -94.4 & 8912.5 \\
\hline 14 & KL-189 & 1 & 6 & 1 & 3 & 2 & 1 & 50 & 132.4 & -82.4 & 6790.8 \\
\hline 15 & KL-190 & 1 & 6 & 1 & 3 & 9 & 1 & 57 & 132.4 & -75.4 & 5686.1 \\
\hline 16 & KL-191 & 4 & 6 & 2 & 3 & 6 & 1 & 90 & 132.4 & -42.4 & 1798.3 \\
\hline 17 & KL-192 & 1 & 6 & 4 & 3 & 1 & 1 & 222 & 132.4 & 89.6 & 8027.0 \\
\hline 18 & KL-193 & 3 & 6 & 1 & 3 & 8 & 1 & 71 & 132.4 & -61.4 & 3770.7 \\
\hline 19 & KL-194 & 2 & 6 & 1 & 3 & 9 & 1 & 78 & 132.4 & -54.4 & 2960.0 \\
\hline 20 & KL-195 & 6 & 6 & 6 & 3 & 2 & 1 & 242 & 132.4 & 109.6 & 12010.8 \\
\hline 21 & KL-196 & 7 & 6 & 3 & 3 & 1 & 1 & 152 & 132.4 & 19.6 & 383.9 \\
\hline 22 & KL-197 & 7 & 6 & 4 & 3 & 1 & 1 & 186 & 132.4 & 53.6 & 2872.3 \\
\hline 23 & KL-198 & 3 & 6 & 2 & 3 & 1 & 1 & 116 & 132.4 & -16.4 & 269.2 \\
\hline 24 & KL-199 & 1 & 6 & 9 & 3 & 2 & 1 & 35 & 132.4 & -97.4 & 9488.0 \\
\hline 25 & KL-200 & 7 & 6 & 4 & 3 & 1 & 1 & 186 & 132.4 & 53.6 & 2872.3 \\
\hline 26 & KL-202 & 1 & 6 & 1 & 3 & 1 & 1 & 63 & 132.4 & -69.4 & 4817.2 \\
\hline 27 & KL-203 & 6 & 6 & 2 & 3 & 1 & 1 & 118 & 132.4 & -14.4 & 207.5 \\
\hline 28 & KL-204 & 6 & 6 & 2 & 3 & 1 & 1 & 120 & 132.4 & -12.4 & 153.9 \\
\hline 29 & KL-205 & 9 & 6 & 2 & 3 & 1 & 1 & 152 & 132.4 & 19.6 & 383.9 \\
\hline 30 & KL-206 & 4 & 6 & 1 & 3 & 9 & 1 & 66 & 132.4 & -66.4 & 4409.8 \\
\hline 31 & KL-207 & 6 & 6 & 2 & 3 & 1 & 1 & 109 & 132.4 & -23.4 & 547.9 \\
\hline 32 & KL-208 & 7 & 6 & 2 & 3 & 1 & 1 & 136 & 132.4 & 3.6 & 12.9 \\
\hline
\end{tabular}

\begin{tabular}{|c|c|}
\hline Average & 132.41 \\
\hline Standard Deviation & 71.87 \\
\hline Threshold Value & 240 \\
\hline
\end{tabular}

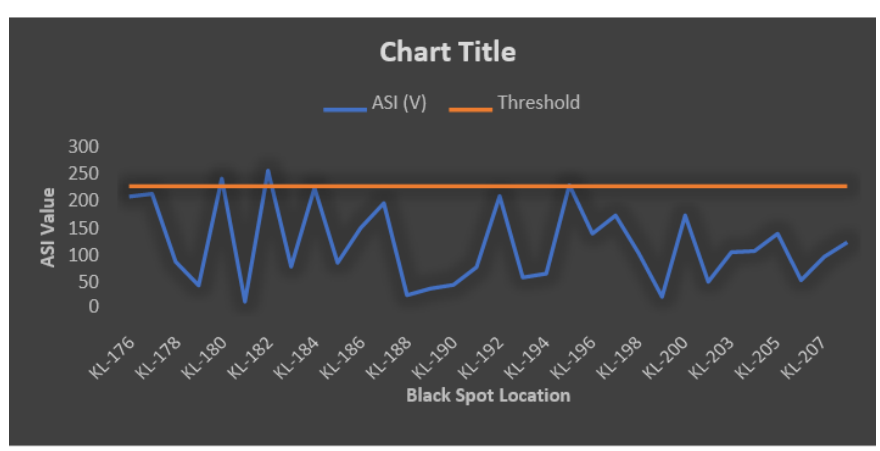

Figure 4. Accident Severity Index and Threshold Values

\section{VII.MITIGATION OF BLACK SPOTS}

Based on site inspection, preliminary survey etc. the type of implementation required may be identified and accordingly the action for taking corrective measures i.e., short term measures and Long-term Measures may be initiated at Authority's Level. As per the requirement of site (Black Spot location) the corrective measures i.e. Short Term Measures only, and in some cases Long Term Measures including Cautionary Measures\&/or Short-Term Measures may be taken.

The suggestive measures and recommendation to be followed for rectifications of black spots are as under: 
Short term measures: The suggestive items or measures are as under:

i. Pedestrian facilities like Zebra crossings ii. Crash barriers/ railings

iii. Solar light

iv. Junction's improvement

v. Road signs inter-alia speed limits sign, pavement/road markings, delineators, studs/ cats' eye.

vi. Providing rumble strip for traffic calming.

vii. Repairing or maintenance of unsafe road including filling of shoulder on National

Highways

viii. Restriction of certain types of vehicles, one-way streets, reversible lanes, bus lanes, restriction on movement of different types of vehicles at a time etc. specially in urban areas.

\section{CONCLUSION}

This study is an attempt to find out the blackspots in Kerala. The Accident Severity Index (ASI) method was used to rank the accident locations. This method was found to be effective in identifying the blackspots. Based on the analysis, and the results, ASI is 132.41, Standard Deviation is 71.87, Threshold Value is 240. we proposed the short-term measures for the blackspots until the long-term measures come into exitance.

\section{REFERENCES}

[1]. Riadh, H., Fedi, O., Rafa, M. (2016). “Detection and Classification of Road Accident Black

[2]. Zones Using Exploratory Spatial Data Techniques." International Journals of Trend in

[3]. Research and Development. 3 (1), 2394-9333.

[4]. Chen, H. (2012). "Black Spot Determination of Traffic Accident Locations and Its Spatial Association Characteristic Analysis Based on
GIS.” Journal of Geographic Information System, 2012. 4, 608-617

[5]. Medury A., Grembek O. (2016). "Dynamic programming-based hot spot identification approach for pedestrian crashes."Accident Analysis \& Prevention. 93, 198-206.

[6]. Ghodmare S.D., Bajaj P., Khode B.V. (2019). "Comparative Analysis of BRTS and MRTS-an Approach Required for Selection of System."Smart Technologies for Energy, Environment and Sustainable Development. 465-477.

[7]. Vyas P. R., Honnappanavar M. L., Balakrishna H. B. (2015). "Identification of black spots for safe commuting using weighted severity index and GIS." International Journal of Advanced Structures and Geotechnical Engineering. 04, 2319-5347.

[8]. Ghodmare. S. D., Khode. B.V., Bajaj P. (2019). "Application of The Multi Attribute Utility Technique with its For Sustainability Evaluation of Emerging Metropolitan City of Nagpur." International Journal of Civil Engineering and Technology (IJCIET). 10 (1)942- 950.

[9]. Katre, N. and Pitale, N. H. (2019). "Analysis of Black Spots and Its Rectification - A Review." International Journal for Research in Applied Science \& Engineering Technology (IJRASET). 7(4), 1794-1796.

[10]. Mandloi, D. and Gupta, R. (2003). "Evaluation of accident black spots on roads using Geographical Information Systems (GIS).” Map India Conference 2003.

[11]. Apparao. G., Mallikarjunareddy P. Dr. Raju G. (2013). "Identification of Accident Black Spots for National Highway Using GIS.” International Journal of Scientific \& Technology Research. 2(2), 154-157.

[12]. Metre K., Baghel H., Suman G., Batra M., Ghodmare S.D. (2021). "Compact City and Related Impact on Sustainable Development in 
Urban Areas." Advances in Civil Engineering and Infrastructural Development. 523-530.

[13]. Wu, L., Chu, J., Ci, Y., Feng, S. and Liu, X. (2015). "Engineering Solutions to Enhance Traffic Safety Performance on Two-Lane Highways." Hindawi Publishing Corporation Mathematical Problems in Engineering.2015, 17.

[14]. Raju, G. (2007). "Assessment of Noise level due to vehicular traffic at Warangal city, India." International Journal of Environment and Pollution. 30. (1), 137-153.

[15]. Bhuyan, P. K. (2002). "Accidents Analysis on Two Lane Road." Unpublished Seminar Report, Department of Civil Engineering, Indian Institute of Technology Roorkee.

[16]. Garber, N. J. and Hoel, L. A. (2002). "Traffic and Highway Engineering." Third Edition, Thomson Publishing Company, New York. 131-172.

[17]. Jain, S. S., Parida, M., Chauhan, M. P. S. and Landge, V. S. (2004). "Identification of Hazardous Locations on National Highways." International Conference on Transportation Systems Planning and Operation (TRANSPO 2004), Chennai.

[18]. Raju, G. (2012). “Identification of black spots and junction improvements in Visakhapatnam City." Indian Journal of Innovations and Development. 1 (6), 469-471.

[19]. Jain, S. S., Parida, M., Chauhan, M. P. S. and Landge, V. S. (2004). "Development of an Alternative Method for Identification of Hazardous Location." National Seminar on Strategies in Traffic Engineering and Management (STEM -04), Bangalore.

[20]. Nadaf, A. M. (1999). "Accident and Drivers." Indian Journal of Transport management. 23 (6), 361-369.

[21]. Sarin, S. M. (1998). "Road Traffic Safety in Indian Issues and Challenges Ahead." Indian Highways. 26 (6), 26-38.
[22]. Singh, H. N., and Sharma, M. (2002) "Report on Road and Traffic Safety." COTE, IIT- Roorkee.

[23]. Sinha, R. P. (2001). "Anatomy of Accidents." Newsletter, the Indian Roads and Transport development Association (IRTDA). LXX (10).

[24]. Raju, G. (2011). "Vehicular Growth and Its Management in Visakhapatnam City - Case Study." Indian Journal of Science and Technology. 4 (8), 903 - 906.

[25]. Bairwa, H. R. (2002). "A Study on Accident Black Spots on National Highway." Unpublished ME Dissertation, Department of Civil Engineering, Indian Institute of Technology Roorkee

\section{Cite this article as :}

Dinesh K Yadav, Sujesh D. Ghodmare, N. Naveen Kumar, "Mitigation Of Black-Spot's on Highways by The Application of Safe System Approach", International Journal of Scientific Research in Science and Technology (IJSRST), Online ISSN : 2395-602X, Print ISSN : 2395-6011, Volume 8 Issue 4, pp. 583-591, July-August 2021. Available at doi : https://doi.org/10.32628/IJSRST218492 Journal URL : https://ijsrst.com/IJSRST218492 